Studia z Dziejów Średniowiecza, t. 24, 2020

\author{
Joanna Sobiesiak \\ (Uniwersytet Marii Curie-Skłodowskiej w Lublinie) \\ orcid: https://orcid.org/0000-0002-3590-5956
}

\title{
Mediewalizm w malarstwie czeskim XIX wieku. Zwycięstwo pod Mediolanem 1158 roku i inne kluczowe wydarzenia epoki średniowiecza budujące tożsamość wspólnoty Czechów ${ }^{1}$
}

Keywords: medievalism, Władysław II, the Battle of Milan (1158), Karel Svoboda

W artykule skupimy się na wykładni historii doby Przemyślidów, obecnej w czeskim malarstwie historycznym XIX i początku XX w. Odniesienia w sztuce do czasów panowania tej dynastii były niezwykle istotne dla budowania tożsamości wspólnoty, ponieważ za rządów Przemyślidów dokonały się wszystkie fundamentalne wydarzenia, ważne dla organizującego się państwa i narodu czeskiego. Szczególną uwagę pragnę zwrócić na jeden z epizodów czeskiej historii doby Przemyślidów, również obecny w treściach podejmowanych przez XIX-wiecznych artystów. Interesują nas rządy drugiego króla czeskiego, Władysława II (1140-1172), ponieważ był drugim koronowanym czeskim władca w okresie, kiedy Czechy pozostawały księstwem, czyli nie istniała tam

1 Tekst powstał w ramach projektu NCN Opus 13, nr projektu 2017/25/B/ HS3/02442: Tradycja o zwycięstwie wojsk króla Wtadystawa I pod Mediolanem (1158 r.) jako składnik czeskiej średniowiecznej i nowożytnej pamięci historycznej. 
tradycja funkcjonowania władzy królewskiej. Co więcej, przez nieco późniejszą w stosunku do panowania Władysława, średniowieczną historiografię - chodzi o Kronikę tzw. Dalimila władca ten był oceniany negatywnie, a to z powodu jego bliskiej współpracy z Fryderykiem Barbarossą i - jak się wydaje - jego monarszych ambicji.

W tradycji każdej społeczności odwoływanie się do przeszłych chwalebnych dziejów wspólnoty stanowi ważny element budowania i podtrzymywania samoświadomości danej grupy/narodu. Nie inaczej rzecz się miała z Czechami. Wspólnota, która przez kilkaset lat posiadała własne państwo założone przez przedstawiciela rodzimej dynastii - Przemyślidów, od pierwszej połowy XVI w. była poddawana swego rodzaju kulturowemu wynarodowieniu. Panowanie Habsburgów, trwające do powstania Czechosłowacji w 1918 r., było okresem, w którym rodzimy żywioł czeski zastępowały nowe rody możnowładcze, które przynosiły ze sobą do Czech obcy język i tradycję ${ }^{2}$. Z końcem XVIII w. rozpoczął się w Czechach tzw. okres odrodzenia narodowego, przypada on umownie na lata 1781-1848. Ta epoka „odrodzenia” nadal jest uważana w czeskiej tradycji za udana misję uratowania narodu ${ }^{3}$. Wraz z odrodzeniem literatury czeskiej i języka czeskiego nastapił wzrost zainteresowania rodzimą historią i tymi jej epizodami, które można było wykorzystać jako fundament kulturowy przy odbudowywaniu tożsamości narodowej Czechów żyjących w wielonarodowej monarchii habsburskiej. Metaforyczne postrzeganie „odrodzenia” ustaliło się w odniesieniu do mitu o wspaniałej przeszłości wspólnoty, po której nastapił „upadek narodu”, by ostatecznie dojść właśnie do wskrzeszenia czeskiej świadomości narodowej. Ta romantyczna idea „budzenia się małych narodów” w dużej mierze opierała się na odwoływaniu się do ich historycznych korzeni - w całej Europie można w tym okresie dostrzec wzmożenie zainteresowania średniowieczem ${ }^{4}$. Owo zainteresowanie znalazło wyraz również $\mathrm{w}$ rozwinięciu się malarstwa historycznego.

2 R. Šimůnek, Obraz šlechtického panství v Čechách 1500-1750, Praha 2018, s. 367-369; Dějiny v obrazech. Historické náměty v uměni 19. století v Čechách, red. N. Blažíčková-Horová, Národní galerie v Praze, Praha 1996, s. 9.

3 Z. Tarajło-Lipowska, Historia literatury czeskiej. Zarys, Wrocław 2010, s. $89-91$.

4 Ibidem, s. 99. 
Malarstwo historyczne XIX w. w Europie było, obok pomników, jednym $\mathrm{z}$ ważniejszych środków narodowej autoprezentacji ${ }^{5}$. Należy zatem uznać tę formę przekazu za bardzo ważny składnik w procesie formowania się historycznego pojęcia czeskiego narodu. Początkowe romantyczne upodobanie do malowania scen historycznych zmieniło się z czasem w swego rodzaju program polityczny. Razem z literatura traktująca o przeszłości Czechów i dramatem teatralnym malarstwo historyczne budowało legitymizację czeskiego państwa i narodu, miało za zadanie wychowywać ów naród w tradycji tego, co własne i rodzime ${ }^{6}$. Początkowo miało ono charakter dydaktyczno-popularyzatorski, by z czasem zyskać wymiar polityczny, a nawet dokumentalny. Jak twierdzą badacze, rzadko impulsem do tworzenia dzieł o tematyce historycznej było zainteresowanie przeszłościa, powstawały one raczej jako zapotrzebowanie na patriotyzm i nacjonalizm. Połączyły się więc postulaty oświecenia, czyli edukacja z edukowaniem poprzez sztukę

Tematyka malarska nawiązująca do epoki Przemyślidów jest niezwykle bogata. W wydanym na początku XX w. albumie Historie českého národa v obrazech. Vypráví o slavné minulosti i utrpení českého národa od nejstaršich českých pověstí až po události minulého stoleti ${ }^{8}$ zamieszczono 100 reprodukcji autorstwa różnych malarzy, przedstawiających historię Czech po wiek XIX. Oczywiście dużą popularnością pośród historycznych treści malarskich cieszyły się tematy związane $\mathrm{z}$ wojnami husyckimi, jednak ponad jedna czwarta reprodukcji (29 miniatur) odnosi się do okresu rządów Przemyślidów, czyli do okresu w którym Czesi posiadali rządzone przez rodzimą dynastię państwo czasu, w którym odnosili sukcesy militarne. Nie jest naszym zadaniem wymienienie wszystkich reprodukcji zamieszczonych w rzeczonym albumie,

5 F. Büttner, Wzlot i upadek malarstwa historycznego. Historia i teoria gatunku w Niemczech od schytku XVIII do poczattów XX wieku [w:] Nauczyciele Matejki, Grottgera, Gierymskich... Monachijskie malarstwo historyczne XIX wieku: wystawa w Muzeum Narodowym w Krakowie, marzec-czerwiec 2007, red. W. Bałus, B. Ciciora-Czwórnóg, Kraków 2007, s. 13-37, tu s. 13, 22.

6 Dějiny v obrazech..., s. 9.

7 F. Büttner, Wzlot i upadek malarstwa..., s. 13.

8 Historie českého národa v obrazech. Vypráví o slavné minulosti $i$ utrpení českého národa od nejstaršich českých pověstí až po události minulého století. Dílo, obsahující 100 uměleckých obrazů od slav A. Liebschera, Václava Brožíka, J. Mathausera, V.H. Brunnera, Jana Skramlíka, Věnceslava Černého,Terezín 1930. 
chcemy przywołać te tematy, które były najczęściej podejmowane przez XIX-wiecznych malarzy czeskich.

Bardzo popularne w malarstwie historycznym były tematy odnoszące się do początków wspólnoty: przedstawienia legendarnej wieszczki i pierwszej czeskiej księżnej Libuszy, małżonki założyciela dynastii - Przemysła Oracza. Zainteresowania ta tematyka sięgaja końca XVIII w., kiedy jeszcze w malarstwie historycznym większą popularnością cieszyły się motywy biblijne lub antyczne $^{9}$. Jest to również okres, w którym bardziej popularny niż malarstwo był rysunek czy akwaforta. Za przykład niech nam posłuży praca Ludvika Kohla, którego można uznać za przedstawiciela klasycyzmu. W cyklu prac „Böhmische Geschichte in Bildern" (1788 r.) znajduje się rycina zatytułowana Poselství u Přemysla Oráče, przechowywana w Galerii Narodowej w Pradze ${ }^{10}$. Kohla uważa się za prekursora przejścia w historycznej tematyce malarskiej od motywów antycznych do tematyki narodowej ${ }^{11}$.

Ten sam motyw, witającej Przemysła Libuszy, znajdujemy na wklejce pod numerem $4 \mathrm{w}$ przywołanym wyżej albumie Historie českého národa v obrazech. Autorem obrazu jest Josef Mathauser, artysta urodzony w 1846 r. w Pradze. Bez watpienie może być uważany za jednego z głównych twórców malarstwa historycznego w Czechach ${ }^{12}$. Jest też autorem obrazu Walka dziewic (1907 r., olej na płótnie $)^{13}$. Opowieść, która posłużyła autorowi za temat obrazu, znana jest z XII-wiecznej kroniki Kosmasa, pierwszej czeskiej kroniki, później była powtarzana i rozwijana przez kolejnych średniowiecznych i nowożytnych autorów ${ }^{14}$.

W malarstwie historycznym często portretowano władców i świętych narodowych. Świetnym przykładem wyboru tematyki,

9 M. Huig, Cyklus maleb v královském letohrádku aneb neúspěšné počátky monumentálního malírstvív Čechách [w:] Historická malbav Čechách, škola Christiana Rubena, red. V. Vlans, Praha 1996, s. 14.

10 Dějiny v obrazech..., s. 11.

11 M. Huig, Cyklus maleb..., s. 15.

12 P.H. Toman, Nový slovník československých výtvarných umělců, dil 2, Praha 2000, s. 109.

13 Díčí válka, https://commons.wikimedia.org/wiki/File:Josef-mathauser-divci-valka.jpg (dostęp: 28.10.2020).

14 O znaczeniu dla społeczności mitu o pokonaniu walecznych kobiet zob. J. Banaszkiewicz, Watek „ujarzmienia kobiet” jako składnik tradycji o narodzinach społeczności cywilizowanej. Przekazy „słowiańskie” wcześniejszego średniowiecza [w:] idem, Takie sobie średniowieczne bajeczki, Kraków 2012, s. 308-312. 
która w sposób mocny i jednoznaczny wskazywała Czechom genezę wielkości ich wspólnoty, jest jeden z obrazów Josefa Hellicha (1807-1880 $)^{15}$. Dzieło zatytułowane Św. Ludmiła i ksiażę Borzywoj uczacy w Budeczu św. Wacława (olej na płótnie) znajduje się obecnie w Galerii Narodowej w Pradze ${ }^{16}$. W jednej kompozycji umieszczono trzy bardzo ważne dla samoidentyfikacji Czechów postacie jako wspólnoty zwartej i nawet w pewien sposób wybranej i błogosławionej przez Boga. Mamy tu więc pierwszego chrześcijańskiego księcia Czechów - tego, który w imieniu wspólnoty przyją chrzest - w towarzystwie małżonki Ludmiły, uznanej za święta już w końcu X w. Obok nich artysta umieścił małego chłopca. Jest nim wnuk tej pary, święty Wacław ${ }^{17}$. Postać bez wątpienia najważniejsza dla Czechów nie tylko w dobie przemyślidzkiej, ale i w czasach późniejszych. Wacław, święty ksiązę i jednocześnie patron ziemi, był dla Czechów pośrednikiem pomiędzy nimi a stwórca - Rex perpetuus - władca wiecznie panującym w niebie, natomiast siebie Czesi nazywaja, już w przekazach z początku XII w., familia sancti Wenceslai-czeladzią świętego Wacława ${ }^{18}$. Na prezentowanym obrazie warto zwrócić uwagę na jeszcze jeden detal silnie odwołujący się do historycznej świetności Czechów. Oto z prawej strony obrazu jest umieszczona tarcza niosaca w srebrnym polu herb czarnej orlicy/jednogłowego orła. Jest to najstarszy herb czeskich władców z dynastii Przemyślidów, wyparty w pierwszej połowie XIII w. przez wyobrażenie białego dwuogonowego lwa/lwicy ${ }^{19}$. Rozwój czeskiej heraldyki jest tematem dość skomplikowanym, niemniej już w późnośredniowiecznej tradycji znajdujemy informacje, że zamiana znaku dynastycznego, czyli w zasadzie herbu/godła średniowiecznego państwa dokonała się niejako z inicjatywy cesarza, a na pewno na skutek zbliżenia politycznego z Rzeszą ${ }^{20}$. Mamy zatem w symbolu czarnego

15 České malírství 19. století, red. N. Blažíčková-Horová, Praha 1998.

16 Sv. Ludmila a kniže Bořivoj vyučuji sv.Václava, https://cs.wikipedia. org/wiki/Josef_Vojt\%C4\%9Bch_Hellich\#/media/Soubor:Hellich-Wenceslaus.jpg (dostęp: 28.10.2020).

17 A. Kuźmiuk-Ciekanowska, Święty i historia. Dynastia Przemyślidów i jej bohaterowie w dziele mnicha Krystiana, Kraków 2007, passim.

18 D. Třeštík, Kosmova kronika. Studie k počátkům českého dějepisectví a politického myšlení, Praha 1968, s. 215-231.

19 Česká panovnická a státní symbolika. Vývoj od středověku do současností, red. P. Sedláček, E. Gregorovičová, Praha 2002.

20 Więcej na ten temat zob.: J. Žemlička, Počátky Čech královských 1198-1253. Proměna státu a společnosti, Praha 2002, s. 578-580; J. Sobiesiak, Tradycja o oble- 
orła/orlicy bezpośrednie odwołanie do rodzimej, własnej, jeszcze nieskażonej obcymi (tu niemieckimi wpływami), chwalebnej przeszłości. Działalność Josefa Hellicha możemy wziąć za przykład współdziałania artysty malarza z pisarzem/historykiem w ramach programu zachowania w Czechach narodowego dziedzictwa przez odwołanie do wspólnej przeszłości. Hellich w 1845 r. zilustrował pracę profesora Jana Erazima Vocela - do twórczości tego uczonego jeszcze wrócimy - O starožitnostech českých a o potřebě chrániti je před zkázou ${ }^{21}$.

Bardzo popularnym tematem malarskich wyobrażeń jest scena spotkania księcia Udalryka (+ 1034) z wieśniaczką Bożena, która bardzo plastycznie opisał Kosmas z Pragi. Bożena została matka Brzetysława, jednego z wybitniejszych czeskich władców XI w. Kronikarz Kosmas nazywa go czeskim Achillesem ${ }^{22}$. Przytoczmy ten krótki fragment $\mathrm{z}$ tekstu kroniki, mówiący o księciu Udalryku:

[...] z prawowitego małżeństwa nie urodziło mu się potomstwo, z powodu niepłodności małżonki, lecz z pewnej niewiasty imieniem Bożena, która była żoną Krzesiny, spłodził syna najprzedniejszej urody, którego kazał nazwać Brzetysławem. Jednego dnia, gdy mianowicie wracał z polowania przez wieś chłopska, tę, o której mówiliśmy, niewiastę zobaczył przy studni piorąca szaty i obejrzawszy ją od głowy aż do stóp, zakosztował sercem niemałych ogni miłości. Była bowiem cudnych kształtów ciała, bielsza od śniegu, giętsza od łabędzia, bardziej lśniąca od starej kości słoniowej, piękniejsza od szafiru. Książę, natychmiast posławszy po nia, wzią ją do siebie ${ }^{23}$.

Ta opowieść to oczywiście topos wywodzący się z opowieści biblijnej o królu Dawidzie, który zobaczył myjąca się Betszebę, żonę Uriasza, zabrał ją mężowi i ze związku tego narodził się Salomon. W warunkach europejskiego średniowiecza bardzo

żeniu Mediolanu 1158 roku w Kronice tzw. Dalimila [w:] Historia Narrat. Studia mediewistyczne, red. A. Pleszczyński, J. Sobiesiak, M. Tomaszek, P. Tyszka, Lublin 2012, s. 205-219.

21 Josef Vojtěch Hellich (1807-1880). Inventár osobního fondu, ed. L. Večerníková, Praha 2017, s. 1.

22 Cosmae Pragensis Chronica Boemorum, ed. B. Bretholz [w:] MGH SRG, Nova series, Bd. 2, Berlin 1923, s. 203.

23 Tekst w przekładzie Marii Wojciechowskiej, Kosmasa Kronika Czechów, I/36, Warszawa 1968, s. 174-175. 
popularna była też opowieść o księciu normandzkim Robercie, który zobaczył piorąca w potoku Arletę/Herlettę, córkę kuśnierza/grabarza, wziął ją do siebie, a ona urodziła mu przesławnego syna - Wilhelma Zdobywcę ${ }^{24}$.

Opowieść o spotkaniu Udalryka i Bożeny była powtarzana przez czeskich historyków doby nowożytnej. Szczególna popularność zyskała dzięki Wacławowi Hajkowi z Liboczan (1541), który - co nieco ubarwiając przekaz - zamieścił go w swojej Kronice czeskiej ${ }^{25}$.

Ten malarski temat jako pierwszy podją Austriak Josef Bergler (1801) - to bardzo ważna postać dla rozwoju czeskiego malarstwa, był on pierwszym kierownikiem/dyrektorem świeżo założonej Akademii Sztuk Pięknych w Pradze ${ }^{26}$. Artysta, który kilkakrotnie malował spotkanie Udalryka z Bożena, jest Antonin Machek (1775-1844) ${ }^{27}$. Motyw spotkania czy też jakiegoś związku z wieśniaczka - uosabiajacca siły natury - był dość popularny w końcu XVIII w. Tu jednak możemy dopatrzeć się czegoś więcej niż tylko powielenia modnej tematyki. Otóż jest to bez watpienia pochwała wyboru, jakiego dokonał przemyślidzki dynasta, biorąc na matkę swego syna i następcy kobietę z własnej wspólnoty, a nie Niemkę $e^{28}$. Jeden z czeskich kronikarzy późniejszego średniowiecza, tzw. Dalimil, mocno potępiał tych czeskich władców, którzy żenili się z Niemkami ${ }^{29}$. W powszechnej świadomości wspólnoty wybór Udalryka okazał się jak najtrafniejszy, wszak to czeska wieśniaczka powiła Nowego Achillesa - księcia Brzetysława ${ }^{30}$. Motyw spotkania Udalryka i Bożeny był bardzo popularny w czeskim

24 B. Krzemieńska, Břetislav I. Čechy a středni Evropa v prvé polovinĕ XI. stoleti, Praha 1999, s. 194-196.

25 Z. Tarajło-Lipowska, Historia..., s. 48-50.

26 Dějiny v obrazech..., s. 12-14.

27 České malířství..., s. 17; Dějiny v obrazech..., s. 23-25. Obraz powstał w $1828 \mathrm{r}$.

28 Na ten temat zob. J. Rak, Jak se $z$ únosu stane vlastenecká ctnost aneb Oldřich a Božena a Břetislav a Jitka v optice českého obrození [w:] Dějiny ve věku nejistot. Sborník k př́ležitosti 70. narozenin Dušana Třeštíka, Praha 2003, s. 251-258.

29 J. Sobiesiak, Czechs and Germans: Nationals and Foreigners in the Work of Czech Chroniclers: from Cosmas of Prague (12 $2^{\text {th }}$ Century) to the Chronicle of the So-called Dalimil (14 ${ }^{\text {th }}$ Century) [w:] Imagined Communities. Constructing Collective Identities in Medieval Europe, eds. A. Pleszczyński, J. Sobiesiak, M. Tomaszek, P. Tyszka, Brill 2018, s. 322-334, tu s. 327-328.

30 Dějiny v obrazech..., s. 23. 
malarstwie XIX w. ${ }^{31}$ Podejmowali go między innymi: przedstawiciel romantyzmu Josef Manes, 1820-1871 (1840, olej na płótnie, Galeria Narodowa w Pradze) ${ }^{32}$; Petr Maixner, 1831-1884 (1876, Galeria Narodowa w Pradze - dwukrotnie) ${ }^{33}$ czy Fratnišek Ženišek, 1849-1916 - artysta zaliczany do grupy tzw. patriotycznych malarzy (vlasteneckých umělců) - (1884, olej na płótnie, Galeria Narodowa w Pradze) ${ }^{34}$. Obok niego do tej grupy sa zaliczani: Josef Václav Myslbek, Vojtěch Hynais, Václav Brožík, Josef Tulka, Julius Mařák, Adolf Liebscher, Mikoláš Alešs ${ }^{35}$.

Wśród takich, można powiedzieć oczywistych tematów - które podejmowali rodzimi artyści - pokazujących wielką historię czeskiej wspólnoty, znalazły się również epizody związane z panowaniem drugiego króla czeskiego Władysława II. Problematyka odnosząca się do jego rządów i pamięci o nich w czeskiej społeczności jest szczególnie interesująca, ponieważ koronacja Władysława w 1158 r. i jego późniejsze monarsze poczynania były przez czeską średniowieczną wspólnotę oceniane nie zawsze przychylnie. Na przykład nic nam nie wiadomo, aby Władysław tronował w Pradze w królewskim majestacie, w chwale królewskiego dostojeństwa. Pojawiał się jedynie na zjazdach dostojników Rzeszy ${ }^{36}$. Nic też nie wiemy o koniecznym w sakralnym wymiarze dopełnieniu rytu koronacyjnego, jakim było pomazanie ${ }^{37}$. Przesłanki te sugeruja że „królewskość” Władysława mogła być w Czechach postrzegana jako pewien rodzaj nielojalności

31 W swojej literackiej twórczości do wątków znanych z podań narodowych odwoływał się między innymi Józef Jungmann (1773-1847). Do jego dzieł należą poematy: Otdrzych i Bożena (1806) i Krok (1821), zob. J. Magnuszewski, Historia literatury czeskiej, Ossolineum 1973, s. 112-113.

32 Oldřich a Božena, https://gallery.lulja.com/artist/Josef_Manes/painting. php?i=Josef-Manes--Oldrich-a-Bozena.jpg (dostęp: 28.10.2020).

33 Nová encyklopedie českého výtvarného umění, ed. A. Horová, I. (A-M), Praha 1995 , s. 469.

34 Oldřich a Božena, https://pl.wikipedia.org/wiki/Plik:\%C5\%BDen\%C3\%AD\% C5\%A1ek.Old\%C5\%99ich.a.Bo\%C5\%BEena.jpg (dostęp: 28.10.2020).

35 České malířství..., s. 151. J. Kaše, Velké dějiny zemí Koruny české X. 1740-1792, Praha 2001, s. 659; J. Magnuszewski, Historia literatury..., s. 116-117.

36 A. Pleszczyński, Królewskie gesty stowiańskich dynastów w XI wieku na przykładzie Piastów i Przemyślidów [w:] Persona gestus habitusque insignium. Zachowania $i$ atrybuty jako wyznaczniki tożsamości społecznej jednostki w średniowieczu, red. J. Banaszkiewicz, J. Maciejewski, J. Sobiesiak, Lublin 2009, s. 37; zob. też: M. Wihoda, Pruní česká království, Praha 2015, s. 186-189.

37 J. Žemlička, Křižovatky Vladislava II. Co mohl či nemohl druhý český král [w:] Vladislav II. druhý král z Přemyslova rodu. K 850. výroči jeho korunovace, red. M. Mašek, P. Sommer, J. Žemlička, Praha 2009, s. 19. 
wobec starszyzny, która przecież rościła sobie prawo do decydowania o tym, kto ma rządzić Czechami. A przecież był to drugi czeski król w okresie, kiedy w Czechach nie istniała dziedziczność tej godności. Koronę otrzymał w podobnych okolicznościach jak jego dziad, koronowany ponad siedemdziesiąt lat wcześniej, Wratysław II $^{38}$. W obu przypadkach obdarzenie czeskiego księcia koroną królewską wiązało się ze złożeniem przez niego obietnicy udzielenia militarnego wsparcia władcy Rzeszy w jego włoskich kampaniach. Czesi za panowania Władysława czterokrotnie w latach 1158-1166 wyprawiali się zbrojnie przy boku Fryderyka Barbarossy do Italii ${ }^{39}$. Bez watpienia największym sukcesem była pierwsza z ekspedycji. To wtedy Czesi wsławili się odważną przeprawą przez Addę, dzięki czemu armia cesarska mogła przedostać się na drugi brzeg rzeki i pomaszerować pod Mediolan ${ }^{40}$. Współczesne przekazy, nie tylko czeskich autorów, informuja, że Czesi wykazali się męstwem również podczas oblegania i zdobywania Mediolanu. O czeskim królu zaś współczesny niemiecki kronikarz Rahewin napisał, że wypełniał obowiązki zarówno dobrego króla, jak i dzielnego rycerza (,strennui militis et boni regis”) ${ }^{41}$. Po zdobyciu miasta Władysław pośredniczył w rozmowach między Barbarossa a Mediolańczykami o warunkach zawarcia pokoju. Mimo tylu początkowych sukcesów królowi nie udało się u schyłku życia przeprowadzić, jak się wydaje, jednego z najważniejszych zamierzeń politycznych, mianowicie przekazania władzy synowi. Król Władysław nawet abdykował na rzecz potomka, jednak opór czeskich możnych i brak poparcia ze strony Barbarossy udaremniły ten plan $^{42}$. Jak widzimy, już u schyłku panowania drugi król czeski nie

38 P.E. Schramm, Böhmen und das Regnum. Die Verleihungen der Königswürde an die Herzöge von Böhmen (1085/86,1158,1198/1203) [w:] Adel und Kirche. Gerd Tellenbach zum 65. Geburtstag dargebracht von Freunden und Schülern, hrsg. v. J. Fleckenstein, K. Schmid, Freiburg 1968, s. 351-352.

39 J. Volf, Účast českých panovnikư prí řišských výpravách, „Časopis Musea královstvi českého” 1908, R. 82, s. 171-184; idem, Účast českých panouniků při řšských výpravách (Ǎ̌ do počátku interregna), „Časopis Musea královstvi českého” 1907, R. 81, s. 23-36.

40 Vincentii canonici Pragensis Annales, FRB II, ed. J. Emler, Praha 1874, s. 401-460; zob. też: J. Sobiesiak, Od Lechowego Pola (955) do Mediolanu (1158). W stużbie monarchów Rzeszy. Relacje czeskich źródeł narracyjnych o wyprawach Przemyślidów, Lublin 2011, s. 91-104.

${ }^{41}$ Bischof Otto von Freising und Rahewin, Gesta Frederici seu rectius Cronica, ed. F.-J. Schmale [w:] Ausgewählte Quellen zur Deutschen Geschichte des Mittelalters, hrsg. v. R. Buchner, Bd. XVII, Darmstadt 1965, III, 41, s. 478.

42 J. Žemlička, Křžzovatky Vladislava II..., s. 22. 
cieszył się poparciem w ojczyźnie, co zapewne wpłynęło na opinię o jego rządach wśród następnych pokoleń.

Mimo sukcesów militarnych, jakie Czesi odnieśli pod rządami Władysława, swego rodzaju zła sława króla panowała wśród elit przemyślidzkiej społeczności. Dowód na nią znajdujemy w późnośredniowiecznej czeskiej historiografii. Wspomniany przed chwila tzw. Dalimil, autor pierwszej Kroniki czeskiej napisanej po czesku, bardzo negatywnie ocenia rządy Władysława. Utwór zawiera wyraźne antyniemieckie akcenty, kronikarz oskarża Niemców o to, że dążą do zniszczenia narodu czeskiego ${ }^{43}$. Autor traktuje Czechów i Czechy jako obec - wspólnotę jednoczącą czeskich możnych, która przeciwstawia Niemcom i bardzo mocno podkreśla znaczenie wspólnoty przy wyborze władcy. Członkowie wspólnoty tworzacej obec mieli zdecydowanie oponować przeciw jakimkolwiek obcym ingerencjom przy wyborze panującego ${ }^{44}$. Sprzeciw ten był oczywiście szczególnie skierowany przeciw wtrącaniu się cesarza w obsadzanie czeskiego tronu. Podstawowy zarzut, jaki tzw. Dalimil kieruje przeciw Władysławowi, to uleganie niemieckim wpływom, w wyniku czego cesarz Fryderyk Barbarossa bez trudu podporządkował sobie Władysława, dając mu w Ratyzbonie królewską koronę. Co więcej, dziejopis dodaje, że wracając z Ratyzbony, otoczony niemiecką koteria, Władysław miał śmiać się w nos czeskim możnym, że bez ich udziału zdobył koronę królewską ${ }^{45}$. To najbardziej negatywny obraz rządów Władysława, z jakim się spotykamy w historiografii. Kronikarz łączy wypadki z włoskiej wyprawy z 1158 r. nie z Władysławem, ale pierwszym czeskim królem Wratysławem I (1061-1092). Tak zwany Dalimil barwnie i nieco frywolnie opisuje wyprawę. Kronikarz opowiada o sforsowaniu rzeki Addy, powtarza znane z przekazu Wincentego z Pragi, uczestnika wyprawy, imię rycerza, który znalazł ów bród, był nim Odylen/Odolen. Następnie tzw. Dalimil opowiada o zwycięskim

43 Kronika tak řečeneho Dalimila, red. M. Krčmova, H. Vrbová, Praha 1977, s. 197.

44 B. Nowacki, Więzi społeczne i narodowe w Czechach na poczatku XIV wieku $w$ kronice tzw. Dalimila [w:] Przemyślidzi i Piastowie - twórcy i gospodarze średniowiecznych monarchii. Materiaty z konferencji naukowej Gniezno 5-7 maja 2004, red. J. Dobosz, Poznań 2006, s. 164-166; J. Žemlička, Počátky etnického dualismu [w:] Idea českého státu v proměnách staletí, red. J. Pánek, Praha 2008, s. 40-56.

${ }_{45}$ Staročeska kronika tak řečeného Dalimila, Vydáni textu a veškerého textového materiálu, red. J. Daňhelka, K. Hádek, B. Havranék, N. Kvitková, t. 1, Praha 1988, kapitola 66-68, s. 179-181. 
szturmie na miasto i o panicznej ucieczce Włochów. W jego dziele spotykamy się z bardzo ciekawym zabiegiem historycznym. Autor, umniejszając czyny króla Władysława, stara się jednocześnie zachować pamięć o tryumfach Czechów podczas wyprawy na Mediolan ${ }^{46}$.

Mamy więc świadomy zabieg mający na celu zachowanie pamięci o przesławnym zwycięstwie Czechów, z jednoczesnym oddzieleniem go od władcy, którego rządy są źle oceniane. Kronikarz chce z jednej strony opowiedzieć ze szczególną przyganą o królu Władysławie, który - jak twierdzi - chełpił się, że otrzymał koronę królewską bez zgody czeskich możnych, z drugiej - zachować i przekazać pamięć o śmiałych i bohaterskich czynach Czechów. Możemy dopatrywać się w tym fragmencie Kroniki tzw. Dalimila śladów niechęci otaczającej pamięć o rządach tego Przemyślidy. Skoro kronikarz mógł sobie pozwolić na zdeprecjonowanie rządów Władysława i pozbawienie go należnej mu chwały jako przywódcy Czechów w mediolańskiej wyprawie, w dziele przeznaczonym dla Czechów i po czesku napisanym, to pamięć o panowaniu tego króla musiała być w ojczyźnie albo słaba, albo co bardziej prawdopodobne i ciekawe, niechlubna. Wydaje się więc, że w zbiorowej pamięci czeskiej społeczności samodzielnie istniała memoria o sukcesach Czechów pod Mediolanem.

W późniejszym piśmiennictwie czeskim, również pochodzącym z doby luksemburskiej, nie spotkamy już tak negatywnej oceny rządów Władysława. Jednak echo złej sławy króla, tak mocno rozwinięte przez tzw. Dalimila, przetrwało w pamięci wspólnoty. Jeszcze w wydanej w 1863 r. wierszowanej książeczce zatytułowanej Przemyślidzi autorstwa Jana Erazima Vocela (+1871) znajdujemy informacje o niechęci, jaką budził w Czechach królewski tytuł Władysława i zamiar wyruszenia do Italii przy boku Fryderyka Barbarossy. Vocel, w czeskiej historii zaliczany do grupy tzw. budzicieli narodu, daje czytelnikowi rozbudowana opowieść o wyprawie Czechów do Italii. Interesuje go tylko ten epizod z okresu rządów

46 W kronice czytamy, że nim czeskie oddziały dotarły do przedmieść Mediolanu, już zaczęły się tam szerzyć opowieści, że każdy z czeskich rycerzy ma siłę pięciu wyrwidębów i że zjada dzieci. Pogłoski te wzbudziły przerażenie wśród Mediolańczyków. Tak zwany Dalimil donosi, że kiedy to „głupie gadanie” dotarło do uszu czeskiego władcy i jego rycerzy, wpadli oni na pomysł, jak przy pomocy podstępu łatwo zdobyć miasto. Mianowicie ulepili z ciasta figurki dzieci, nadziali je na rożen, upiekli, po czym żarłocznie je pożarli, czym wielu Włochom napędzili ogromnego strachu - mówi Dalimil. Inni z czeskich rycerzy, ubrawszy się w jedna szatę, pogalopowali konno przed miejskie mury. Włosi na ten widok mieli poblednąć z przerażenia, myśląc, że atakują ich piekielne stwory, zob. Dalimil, k. 47, s. 561. 
króla Władysława. Tekst przynosi znane z przekazu Wincentego z Pragi i tzw. Dalimila szczegóły i kończy się znamienną zwrotką:

Tu provolání slavý vojínů českých znělo

Ne všechněch, kabonilo se tu a tam i čelo,

Neb některým se zdalo, že zlatým okovem

Se k cizí říši poutá svobodná Česká zem ${ }^{47}$.

Po tej, z konieczności dość pobieżnej, prezentacji faktów związanych $\mathrm{z}$ rządami drugiego króla czeskiego i przedstawieniu argumentów sugerujących, że w czeskiej społeczności pamięć o jego panowaniu nie była wyłącznie chwalebna, przyjrzyjmy się, jakie wątki związane z panowaniem Władysława stały się tematem dla czeskich malarzy podejmujących w swojej twórczości tematy historyczne. Zacznijmy od przedstawień najbardziej znanych. Sa to dwie ilustracje przeznaczone do anonsowanego na początku tego tekstu albumu Historie českého národa v obrazech. Ich autorem jest Josef Mathauser $^{48}$. Prace te powstały około $1906 \mathrm{r}$. Na pierwszej z nich widzimy Czechów przekraczających włoską rzekę Addę ${ }^{49}$. Na pierwszym planie wyobrażono siedzącego na koniu i szykującego się do pokonania nurtu rzeki króla Władysława - niesie on na hełmie koronę. Wymowa kompozycji zdaje się być jasna - Czesi wyruszają po sławę i prowadzi ich po nia król Władysław. Na drugim obrazie Čechové pred Milánem roku 1158 ponownie w centralnym polu widzimy króla Władysława w hełmie uwieńczonym korona. Przemyślida walczy mieczem, siedząc na stającym dęba rumaku. Uwagę zwracają również tarcze wojowników z herbem srebrnego lwa. Właśnie dzięki temu znakowi rozpoznajemy w rycerzach Czechów. Widzimy, że artysta niezbyt wnikał w zawiłości czeskiej heraldyki, ponieważ znak lwa jako herb Przemyślidów i Czechów pojawił się blisko pięćdziesiąt lat później, bardziej też niż czarna orlica kojarzył się z militarnymi sukcesami Czechów ${ }^{50}$. Mathauser zapewne umieścił na tarczach lwa, aby przeciętny odbiorca, dla którego symbol srebrnego lwa był oczywistym herbem Czechów, mógł łatwo zidentyfikować „swoich”.

47 L.E. Vocel, Přemyslovci, Praha 1863, s. 130.

48 Zob. przyp. 13.

49 Čechové překračují řeku Addu roku 1158, https://commons.wikimedia.org/ wiki/Category:Josef_Mathauser\#/media/File:Adda1.jpg (dostęp: 28.10.2020).

50 G. Scheibelreiter, Heraldik, Wien 2006, s. 48-49. 
Epizody związane z rządami króla Władysława przedstawiał tė̇ inny współczesny Mathauserowi artysta - Věnceslav Černý (1865-1936), malarz, rysownik i, rzec można, ilustrator historyczny. Černý jest autorem wielu ilustracji do powieści historycznych, między innymi do czeskiego wydania Krzyżaków i Potopu Henryka Sienkiewicza ${ }^{51}$. Jest również znany jako artysta współpracujący z pisarzem Aloisem Jiráskiem, który w swoich powieściach (np. Staré povesti české) beletryzował historię czeska. Choć przed przystapieniem do pisania studiował przekazy źródłowe poszczególnych epok, to jego historyczna twórczość ma zdecydowanie charakter „czechocentryczny” 52 . W cyklu rycin Černego znajdujemy obrazek przedstawiajacy walki pod Mediolanem w 1158 r. Artysta wyeksponował walczącego konno Władysława, który - tak jak w pracach Mathausera - ma hełm zwieńczony korona.

Wyobrażenie Władysława II pojawia się też w twórczości wspomnianego już wyżej malarza Antonina Macheka. Artysta ten jest autorem 68 portretów czeskich władców znanych jako Panovnický cyklus. Cykl rozpoczyna się od wyobrażenia mitycznego Kroka - ojca Libuszy - a kończy na portrecie Ferdynada V. Machek, uważany w zasadzie za portrecistę, był uczniem Vaclava Bluma, później studiował w Wiedniu pod kierunkiem Heinricha Fridricha Fügera. Od początku lat 20. XIX w. zajmował się malarstwem historycznym - interesowały go dzieje czeskie, szczególnie doba husycka. W roku 1820 wydał pierwsze sześć ze swoich grafik zatytułowanych - Czeskie dzieje w obrazach ${ }^{53}$.

Sam zamysł malowania czeskich władców ma swoje korzenie w tradycji wspieranej przez czeską szlachtę - chodziło o pokazanie praw i przywilejów czeskich możnych w konfrontacji z absolutystycznymi poczynaniami Habsburgów ${ }^{54}$. Inspiracją dla Macheka mogło być 37 renesansowych wyobrażeń zdobiących Pražský Hrad. Machek jednak nie kopiował tych wizerunków, tylko stworzył własne wyobrażenia czeskich władców ${ }^{55}$. Wizerunek króla

51 P.H. Toman, Nový slovník československých výtvarných umělců, t. 1, Praha 2000, s. 148.

52 Z. Tarajło-Lipowska, Historia..., s. 150-153.

53 České malírství..., s. 17.

54 N. Blažíčková-Horová, Lev a orel. Češi a habsburská monarchie v umění 19. století, Katalog výstavy, red. V. Vlans, Praha 1994, s. 7; zob też: R. Šimůnek, Obraz šlechtického panství..., passim.

55 N. Blažíčková-Horová, Lev a orel..., s. 6. 
Władysława w otoczeniu rodziny został namalowany między rokiem 1828 a 1835 . Niewielkich rozmiarów olej na płótnie $(36,5 \times 27,5 \mathrm{~cm})$ jest przechowywany w Galerii Narodowej w Pradze ${ }^{56}$. Jest to dość schematyczne przedstawienie w duchu idylli biedermeierowskiej ${ }^{57}$, odpowiadające temu, jak zdaniem artysty powinien prezentować się król. Ani korona, ani zbroja nie odpowiadają realiom średniowiecznym. Artysta namalował kilka tematycznych obrazów odnoszacych się do czeskiej historii, jednak Władysławowi poświęcił tylko tę jedna pracę.

Na zakończenie przedstawmy może mniej znany, ale bardzo interesujący obraz ukazujący scenę tryumfu króla Władysława w Mediolanie $^{58}$. Jest to dzieło Karela Svobody z 1863 r. zatytułowane Ukorzenie Mediolańczyków przed cesarzem Fryderykiem Barbarossa i jego sojusznikiem królem czeskim Wtadystawem II. Svoboda był uczniem Christiana Rubena, założyciela szkoły malarstwa historycznego w 1841 r. na praskiej Akademii. Kiedy w 1847 r. Christian Ruben i jego uczniowie przystępowali do przygotowania wizerunków mających ozdobić letni pałac królewski na Hradzie w Pradze, tematyka historyczna została ustalona z jednym z najwybitniejszych ówczesnych czeskich historyków - Františkiem Palackým. Na dwanaście planowanych tematów cztery odnosiły się do doby przemyślidzkiej, nie było wśród nich jednak tematów związanych z panowaniem drugiego czeskiego króla ${ }^{59}$.

W pracach Svobody przebijają się już motywy charakterystyczne dla realizmu ${ }^{60}$. Malarstwo realistyczne było bardzo dobrym narzędziem do kreowania pożądanej wizji zdarzeń z przeszłości. Dawało złudzenie bycia formą dokumentalna, nakierowując jednocześnie nieświadomego odbiorcę na właściwy w sferze ideowej odbiór dzieła ${ }^{61}$.

56 Panovnický cyklus, Vladislav II, https://www.alamy.com/stock-photo-antonin-machek-31-10-1775-18-11-1844-vladislav-ii-panovnicky-cyklus- 134914692. html (dostęp: 28.10.2020).

57 Dějiny v obrazech..., s. 14

58 Milánští před císařem Barbarossou, http://m.foto-renata-jagrova.webnode.cz/ album/fotogalerie-fotogalerie-obrazarna/img-3896-jpg (dostęp: 28.10.2020); zob. też Dějiny v obrazech..., s. 64.

59 M. Huig, Cyklus maleb..., s. 22-23. Podjęte tematy dotyczące doby Przemyślidzkiej to: 1. Przyjęcie chrześcijaństwa w Czechach, 2. Brzetysław z relikwiami św. Wojciecha powracajacy do Pragi, 3. Bitwa pod Chlumcem, 4. Przemysł Ottokar żegnający się z Praga w 1278 r.

60 Dějiny v obrazech..., s. 63.

61 F. Büttner, Wzlot i upadek malarstwa..., s. 27. 
Ukorzenie Mediolańczyków - dużych rozmiarów praca $(266 \times 390 \mathrm{~cm})$, olej na płótnie - znajduje się obecnie w Galerii Narodowej w Pradze. $\mathrm{Na}$ obrazie, w jego centralnej części, widzimy tronującego w majestacie Fryderyka Barbarossę, przed którym znajduje się tłum pokonanych i korzacych się mieszkańców Mediolanu. Po prawej stronie cesarza artysta wyobraził stojącego w majestatycznej pozie Władysława Przemyślidę, wyposażonego w atrybuty godności królewskiej: koronę i berło. Po lewej stronie Barbarossy widzimy postać w biskupim stroju, jest to bez watpienia biskup praski Daniel. Cała kompozycja, sprawiajaca wrażenie „średniowiecznego zdjęcia”, pokazuje tryumf króla Władysława i zaszczyty, które stały się jego udziałem. Artysta - inaczej niż jego poprzednicy, zarówno malarze, jak i pisarze - odnosząc się do przebiegu mediolańskiej wyprawy z 1158 r., skupił uwagę nie tyle na Czechach - uczestnikach ekspedycji - ale na osobie czeskiego monarchy.

Podsumowując, możemy stwierdzić, że mimo niejednoznacznych ocen rządów Władysława, na które się natykamy w czeskiej średniowiecznej i nowożytnej historiografii, osoba tego władcy nie została pominięta $\mathrm{w}$ historycznej tematyce podejmowanej przez czeskich malarzy XIX w. Jednak artyści ci, jeśli już decydowali się podjać temat związany z Władysławem, a jest tych obrazów niewiele, to najczęściej przedstawianym motywem były dzieje pierwszej (tej z 1158 r.) wyprawy króla i Czechów do Italii, a nie na przykład udział Władysława w II wyprawie krzyżowej, która przecież umieszczała czeskiego władcę i tym samym czeską historię zarówno w sferze sacrum, jak i profanum chrześcijańskiego universum ${ }^{62}$. Przedstawiciele różnych stylów i szkół malarskich w swoich pracach nawiązywali do chwalebnej przeszłości wspólnoty Czechów. Choć, jak twierdzą badacze, to romantyzm mocno zakorzenił się w czeskim malarstwie, razem z jego wyjątkowym pojmowaniem idei narodu i jego historii. Idea romantyczna akcentowała również wszystkie symbole rozwijającego się malarstwa historycznego ${ }^{63}$. W malarstwie - które przecież inaczej niż przekazy pisane musiało zwięźle za pomoca symbolu czy alegorii wykładać swój przekaz - król Władysław stawał się czeskim bohaterem. Łącząc

62 Wyprawa ta miała miejsce w 1147 r., czyli już po objęciu przez Władysława władzy w Pradze, a jeszcze przed otrzymaniem korony królewskiej. O wyprawie zob. Velké dějiny zemí Koruny České, red. M. Bláhová, J. Frolík, N. Profantová, t. 1, Praha 1999, s. 592-595.

63 N. Blažíčková-Horová, Lev a orel..., s. 6. 
jego osobę z mediolańską wyprawa, artyści jednoznacznie wskazywali na chwalebny epizod w czeskiej historii, mocno przecież związany z osobą króla. Władysław podczas tej głośnej wyprawy symbolizował wszystkie tryumfy Czechów.

\author{
Abstract \\ Medievalism in Nineteenth-Century Czech Painting. \\ The Battle of Milan in 1158 and Other Key Events \\ of the Medieval Period That Helped to Create Czech \\ Collective Identity
}

This article focusses on the interpretation of the history of the times of the Prremyslid dynasty, an interpretation that is present in Czech historical painting in the nineteenth and early twentieth centuries. It takes a close look at the reign of the Czech king Vladislaus II (1140-1172). He was the second crowned Czech ruler at a time when there was no tradition of royal power and authority. This ruler was negatively assessed in medieval history writing that was somewhat later than his reign. However, in painting, which, after all, must succinctly transmit its message through symbol or allegory, King Vladislaus became a Czech hero. Linking his person to the Milan expedition, artists, who depicted this as an unambiguously praiseworthy episode in Czech history, showed the King as a key figure in those events. Vladislaus symbolized all the triumphs of the Czechs. 